\title{
Cultural Development through Language Styles and Expression of Teenage Girls Identity in Indonesian Teen lit Novel Me Versus High Heels by Maria Ardelia
}

\author{
Redyanto Noor ${ }^{1}$, Arido Laksono ${ }^{2}$, Rukma Kawentar ${ }^{3}$ \\ ${ }^{1}$ Department of Indonesian Literature, Faculty of Humanities, Diponegoro University, Semarang - Indonesia \\ ${ }^{2}$ Department of English, Faculty of Humanities, Diponegoro University, Semarang - Indonesia \\ ${ }^{3}$ Department of English, Faculty of Humanities, Indonsia University, Jakarta - Indonesia
}

\begin{abstract}
In Indonesian teen lit novels, the lifestyle of teenage girls can be interpreted from their way and style of communication, namely the way and style of using language. From the many means of selfdisclosure as anevidence of the very distinctive existence of teenager is the language. For teenager, language is not just a communication tool serving to achieve understanding, but also as a symbol of identity: education, social status, economic status, hobby, groups, communities, and social environment. In a teenage social environment, the language determines the process, type, and form of interaction-communication that affects the acceptability or social arbitrariness. As a result, each individual teenager strives to adjust his or her use of "gaul" (slang) language to achieve the acceptability.
\end{abstract}

Keywords: style; language system; identity; teen-lit

\section{Introduction}

Cultural development defines not only the style of communication but also the way a member of society behaves. The behavior involves awareness toward the surrounding environment where a person lives. It requires responsibilities and sense of belonging upon the sustainability of human-beings. The article on language style and expression reveals the identity of teenage girls in preserving values, norms and social heritage which later also develops the awareness towards low carbon use,

In the novel, of the many indicators that most clearly show the character's personality is the way and style of communication. From the many means of selfdisclosure as an evidence of the very distinctive existence of teenager is the language [1]. In a teenage social environment, language determines the process, type, and form of interaction-communication that affects the acceptability or social rejection. As a result, every teenager strives to adapt his or her language style to the distinctive language of teenagers to achieve acceptance in their social circles, in order to escape the predictions of "kuper", "norak", "culun", or "kutukupret".

\section{Cultural Development as seen in "Gaul" (Slang) Language Styles in the teenlit novel Me Versus High heels}

Here are some excerpts from the novel version of Me Versus High Heels showing the variety of the typical "slang" language of teenagers [2].

(1) "Ngapain malu, Ma? Kan pake baju!" jawab Shasajayus (page 7)

"Ih, Papa, anak sendiri dikatain sapi... Anaknya sapi, papa nyaapa'an dong?" balas Shasa.

Papanya hanya bisa mengelus dada.

(2) Begituisismsmasuk...

Thx. U r my best bestfrnd! 5 mntlggwsmp!

Shasatertawa kecil membaca balasan sms dari temannya (page 9).

(3) Lola diam, bingung. Masalah apalagi yang menimpa sahabatnya itu? .....

"Hah! Cowokmana yang bias bikinloe kayak gini?" Lola kaget.

"Loenaksir?” (page 86-87)

(4) Sepuluh menit setelah pelajaran berlangsung, secarik kertas sampai di hadapan Shasa.

Sha, hrinigwadaacarakeluarga, jadinggak bias ngurusloe. 
Shasa membaca lalu menoleh kearah Lola. Lola mengacungkan ibujarinya. Shasa melotot dan menggeleng, tapi Lola mengangguk dan tetap mengacungkan ibujarinya (page 129-130).

The language style of the discourse in some of the above quotations reveals certain meanings about the teenager's lifestyle, that is, the nature, attitudes, views, and the feelings of the teenager (figure Shasa). For teenager, language is not just a means of communication achieving individual understanding and social acceptability, but it also serves as a symbol of identity, showing the status of education, social, economic, tastes, community, and society. In addition to symbol of identity, teenager's (women) language firmly pointing to the deviations of values from norms commonly understood by society as ideal female stereotypes, which are subtle, gentle, weak, soft and melodic [3]. The differences of the language of women and men are not limited to intonation, but also diction, syntactic structure and semantic meaning. High tone, heavy rhythm, fast tempo, loud vibration; diction, swearing, the structure of a straightforward sentence and a vulgar meaning are male stereotypes. Women speaking such language in a social perspective are thought to defame the dignity of women [4]. In addition to reflecting gender differences, language also shapes social reality, since language is a tool of social regulation, classification and manipulation. Here, woman also seems to be aware of the importance of preserving environment as part of their roles in society. The language of patriarchal society serves to classify society according to the patriarchal order, yet woman shows her gender role through the concern toward environment depicted in the diction and language style she uses.

In Me Versus High Heels, the language of dialog between the characters does not indicate the social stratification of its speakers, either from intonation elements, syntactic synthesis, semantic meaning, or language style. The dialog in quotation (1) confirms that equality of relations between family members has been created. The language Shasa used to communicate with her parents does not show the child's language stereotype to the parent. In the novel, such language style is used by female characters (Shasa and friends) to be accepted by their social community.

The use of "aneh" (strange) words that is not commonly used as a means of communication in society is used to legitimate their youth status. The conversation through the SMS (short message service) language on the quotation (2) shows that the information technology product has changed the language style of the user in communicating. Common language sound symbols are arranged based on consistent systems and rules altered arbitrarily. As a result, the deviation of writing a language in the form of words, terms, sentences, and paragraphs in the SMS language occurs without rule. For example, the word "gue" (I am) is written "gw", the word "buat" (for) is written "bwt", the word "nih" is written "ne", the word "see you" is written "cu", the word " $a k u$ " (I am) written " $Q$ ". etc.Thus, there is social acceptance, not merely as a new epigone but as an orientation of the members of the community concerned.

In the citation (3) the vocabulary of the "slang" language of short and incomplete sentence structure does not cause communication ambiguity between speakers. It confirms the closeness of the relationship between friends within a community. The dialog of the quotation (4) serves to explain the character's characterization. The causative factors of that barriers are behavioral standards, disciplinary methods, differences in treatment, critical attitudes, supervision, rebellion, and prohibiting doctrine.With reference to the ideal norms of society, the family always impose standards of behavior for teenagers: good behavior, diligent, obedient, honest and responsible. Family discipline is strictly enforced to teenagers than to children and adults. The parents' power is the first "doorstop" that must be broken by teenagers to be free fromobligations to meet the standards of behavior, discriminatory treatment, the threat of punishment, and the shackles of independence

\section{Conclusion}

In other words teenagers are shown to have their own language that is capable of expressing certain feelings related to rejection or approval and displeasure or awe, and so on. Here, they also learn the importance of nurturing nature by the use of certain term reflecting their identity as teenager. The ability of the language to express all these feelings is created precisely because creativity utilizes the language as their identity, the "slang" language. It definitely develops new culture among society, which influences the relation among people and it gradualy develops new habit. The habit of expressing opinions, expressing their hearts through the deviation of language usage has transformed into distinctive ways and styles of language within their communities as well as being a form of their lifestyle, which is the lifestyle of adolescents.

\section{References}

1. Elizabeth B. Hurlock, Psikologi Perkembangan: Suatu Pendekatan Sepanjang Rentang Kehidupan (diindon esiakan Istiwidiyanti \&Soedjarwo, Erlangga, Jakarta (1991)

2. Me Versus High Heels! Aku vs Sepatu Hak Tinggi (cetakan ke-5). Maria Ardelia, Gramedia Pustaka Utama, Jakarta (2005).

3. Graddol, David., Joan Swann,Gender Voices: telaahkritisrelasibahasa-jender (diindonesikan A. Muhith), Pedati, Pasuruan (2003).

4. Noor, Redyanto, Gerak Perlawanan Budaya: Kajian sosiologi terhadap produksi, distribusi, resepsi, dangayahidupremaja novel chicklit dan teenlit indonesia. Disrtasi Doktor Program Pascasarjana, UGM, Yogyakarta(2014). 